\title{
PENGARUH DISIPLIN KERJA TERHADAP KINERJA KARYAWAN PADA PT. PANCA KONSTRUKSI DI KABUPATEN BANJAR
}

\author{
Syarkani \\ Fakultas Ekonomi Universitas Achmad Yani Banjarmasin \\ Jl. Achmad Yani Km.5,5 Komp.Stadion Lambung Mangkurat Banjarmasin \\ e-mail : syarkani54@gmail.com
}

\begin{abstract}
The goal to be achieved in this research is to analyze the influence of work discipline on employee performance at PT. Panca Konstruksi in Kabupaten Banjar. This research was designed with a research explanatory analysis with 57 respondents as samples. The instrument used in this study is a questionnaire containing the items of question by using a 5 level Likert scale. While the data analysis using the program SPSS for Windows version 18. From the test results note that work discipline variables significantly affect the performance of employees at PT. Panca Konstruksi in Kabupaten Banjar. Coefficient of determination equal to 0,565 which mean that equal to $56,5 \%$ while the rest $43,5 \%$ influenced by other variable not examined in this research.
\end{abstract}

Keywords: work discipline, performance

\begin{abstract}
Abstrak: Tujuan yang ingin dicapai dalam penelitian ini adalah untuk menganalisis pengaruh disiplin kerja terhadap kinerja karyawan pada PT. Panca Konstruksi di Kabupaten Banjar. Penelitian ini dirancang dengan analisis research explanatory dengan sampel 57 orang responden. Instrumen yang dipergunakan dalam penelitian ini adalah kuesioner yang berisi butir-butir pertanyaan dengan menggunakan skala Likert 5 tingkatan. Sedangkan analisis data menggunakan program SPSS for Windows versi 18. Dari hasil uji diketahui bahwa variabel disiplin kerja berpengaruh signifikan terhadap kinerja karyawan pada PT. Panca Konstruksi di Kabupaten Banjar. Koefisien determinasi sebesar 0,565 yang berarti bahwa sebesar $56,5 \%$ sedangkan sisanya $43,5 \%$ dipengaruhi oleh variabel lain yang tidak diteliti dalam penelitian ini.
\end{abstract}

Kata kunci: disiplin kerja, kinerja

\section{Latar Belakang}

Keberhasilan suatu perusahaan bukan semata-mata ditentukan oleh tenaga kerja atau sumber daya manusia yang berperan merencanakan, melaksanakan dan mengendalikan organisasi yang bersangkutan, melainkan sangat ditentukan oleh pendayagunaan sumber daya manusia itu sendiri. Penggunaan sumber daya manusia memegang peranan penting dan perlu disadari oleh setiap individu dalam suatu organisasi atau perusahaan untuk mengupayakan adanya berbagai cara untuk memelihara disiplin kerja dengan cara berbagai alternatif dan tindakan untuk mendorong setiap individu atau tenaga kerja untuk mampu meningkatkan tenaga kerja. Disiplin adalah prosedur yang mengoreksi atau menghukum bawahan karena melanggar peraturan atau prosedur. Disiplin merupakan bentuk pengendalian diri karyawan dan pelaksanaan yang teratur dan menunjukkan tingkat kesungguhan tim kerja di dalam sebuah organisasi (Simamora, 2006).

Kedisiplinan karyawan dalam suatu instansi atau perusahaan sangat memegang peranan penting disamping faktor-faktor sumber daya manusia yang berkualitas dan yang berdedikasi tinggi untuk dapat mengembangkan suatu instansi atau perusahaan karena sumber daya akan memberikan kemajuan dalam menentukan 
berhasil tidaknya rencana kerja yang telah dibuat atau yang telah direncanakan. Perlu ditempuh adanya suatu jalan keluar yang lebih tepat dan akurat sehingga dapat meningkatkan kinerja karyawan yang optimal terutama di bidang jasa yang ingin dicapai suatu perusahaan melalui peningkatan disiplin karyawan.

Menurut Mangkunegara (2002) kinerja adalah hasil kerja baik secara kualitas maupun kuantitas yang dicapai oleh seseorang dalam melaksanakan tugas sesuai tanggung jawab yang diberikan. Setiap perusahaan akan selalu berusaha agar kinerja setiap karyawan dapat ditingkatkan. Perusahaan dapat meningkatkan kinerja karyawan dengan upaya menciptakan iklim disiplin kerja yang baik, oleh karena itu sudah selayaknya agar mempunyai disiplin kerja yang baik, sebab dengan menciptakan disiplin kerja tersebut diharapkan kinerja karyawan dapat ditingkatkan dan semakin baik.

Setiap perusahaan jika mampu meningkatkan disiplin kerja pada karyawannya maka akan memperoleh keuntungan yang lebih besar, dengan meningkatkan disiplin kerja maka pekerjaan akan lebih cepat diselesaikan, kerusakan akan dapat dikurangi, absensi akan dapat diperkecil dan kemungkinan perputaran karyawan juga dapat diperkecil. Bagi suatu organisasi atau perusahaan terciptanya sumberdaya manusia yang berkualitas merupakan suatu tujuan dimana hal tersebut sangat penting bagi peningkatan kinerja karyawan. Sejalan dengan tujuan tersebut, bagi perusahaan mempunyai masalah terhadap pengembangan disiplin kerja secara optimal, sehingga diharapkan lebih memacu tingkat kinerja karyawan untuk mencapai tujuan yang diharapkan oleh perusahaan.

Masalah tenaga kerja merupakan salah satu unsur pokok dalam mekanisme instansi atau perusahaan lain termasuk PT. Panca Konstruksi, ini tidak hanya di negara kita yang berkembang akan tetapi di negara-negara yang sudah maju di dunia. Setiap perusahaan baik perusahaan besar maupun kecil tidak bisa lepas dari peran tenaga kerja didalamnya, dalam hal ini tenaga kerja atau karyawan yang mempunyai keahlian, tanggung jawab dan loyalitas yang tinggi harus dipertahankan untuk tetap bekerja. Organisasi atau perusahaan pada dasarnya bukan saja menghendaki karyawan yang mampu, cakap dan terampil tetapi yang penting adalah kedisiplinan serta mereka mampu bekerja dengan giat dan berkeinginan untuk mencapai hasil kerja yang maksimal dan dapat meningkatkan kinerja karyawan.

PT. Panca Konstruksi menyadari bahwa suatu kegiatan yang ingin menghasilkan output yang besar, maka tidak terlepas dari kerjasama antara individu-individu yang terlibat dalam organisasi untuk mewujudkan kerja yang baik, setiap perusahaan atau instansi tidak terlepas dari penciptaan suatu disiplin kerja yang ditujukan pada karyawan. Tujuan setiap perusahaan akan selalu berusaha meningkatkan disiplin kerja, sehingga proses kegiatan instansi akan berjalan dengan lancar.

Bagi suatu perusahaan, terciptanya sumber daya manusia yang berkualitas merupakan suatu tujuan, dimana hal tersebut sangat penting bagi peningkatan disiplin kerja, terlebih lagi instansi atau perusahaan yang memiliki misi pelayanan jasa. Sejalan dengan tujuan tersebut, bagi PT. Panca Konstruksi yang bergerak dalam bidang jasa konstruksi mempunyai masalah terhadap disiplin kerja seperti tingkat absensi karyawan yang terlalu tinggi, keterbatasan peralatan kantor yang kurang memadai, kurangnya pengawasan dilapangan sehingga karyawan bekerja kurang baik, penyediaan barang dan pemberian gaji yang tidak tepat pada waktunya, sehingga diharapkan dengan meningkatkan disiplin kerja akan lebih memacu tingkat kinerja karyawan instansi atau perusahaan dalam mencapai tujuan yang diharapkan.

Hasil rekap daftar hadir PT. Panca Konstruksi pada tahun 2016 jumlah karyawan hadir sebanyak $55,91 \%$ dan tidak hadir sebanyak 44,09\%. Dari tahun ke tahun mengalami peningkatan baik itu karena sakit, izin, pelatihan, cuti dan tanpa keterangan, akan tetapi kebanyakan dari karyawan tersebut malah tidak dapat hadir ke kantor tanpa ada keterangan/izin. Terkait permasalahan tersebut, maka peneliti tertarik untuk mengadakan penelitian diperusahaan tersebut. 
Dari hasil observasi dilapangan, maka dapat diidentifikasi bahwa permasalahan disiplin kerja karyawan pada PT. Panca Konstruksi di Kabupaten Banjar adalah adanya tingkat absensi karyawan yang terlalu tinggi, serta kurangnya pengawasan di lapangan sehingga karyawan bekerja kurang baik. Berdasarkan permasalahan diatas maka yang menjadi rumusan masalah dalam penelitian ini adalah apakah disiplin kerja berpengaruh terhadap kinerja karyawan pada PT. Panca Konstruksi di Kabupaten Banjar?

Penelitian yang dilakukan ini diharapkan dapat memberikan nilai guna khususnya mengenai disiplin kerja, yaitu sebagai hasil karya dalam menambah wawasan pengetahuan yang dapat lebih memperluas pola pikir pembaca khususnya mengenai disiplin kerja berkaitan dengan kinerja karyawan, sebagai bahan referensi bagi pihak-pihak yang berkepentingan untuk memperdalam mengenai masalah pengembangan sumber daya manusia di masa yang akan datang khususnya membahas mengenai masalah disiplin kerja terhadap kinerja karyawan, serta sebagai bahan masukan atau perbandingan bagi pihak perusahaan mengenai pentingnya disiplin kerja dalam mempengaruhi kinerja karyawan.

\section{Kajian Literatur}

Hasibuan (2007) menyatakan bahwa kedisiplinan adalah kesadaran dan kesediaan seseorang menaati semua peraturan perusahaan dan norma-norma sosial yang berlaku. Siagian (2008) menyatakan bahwa disiplin merupakan tindakan manajemen untuk mendorong para anggota organisasi memenuhi tuntutan berbagai ketentuan tersebut.

Kedisiplinan lebih tepat kalau diartikan sebagai suatu sikap, tingkah laku dan perbuatan yang sesuai dengan peraturan perusahaan baik yang tertulis maupun tidak (Nitisemitro, 2006). Misalnya suatu perusahaan menetapkan aturan bahwa setiap karyawan tidak boleh meludah disembarang tempat, bila sebagian besar karyawan taat, berarti salah satu kedisiplinan dalam perusahaan tersebut sudah dapat ditegakkan.

Kesimpulan dari pengertian disiplin adalah prosedur yang mengoreksi atau menghukum bawahan karena melanggar peraturan atau prosedur. Disiplin merupakan bentuk pengendalian diri karyawan dan pelaksanaan yang teratur dan menunjukan tingkat kesungguhan tim kerja disebuah organisasi. Tindakan disipliner menuntut suatu hukuman terhadap karyawan yang gagal memenuhi standar-standar yang ditentukan. Tindakan disiplin yang dilaksanakan secara tidak benar adalah destruktif bagi karyawan dan organisasi.

Pemimpin perusahaan harus mampu mengenal dan mempelajari perilaku dan sifat karyawannya, hal ini dapat membantu pemimpin dalam memilih jenis motivasi kerja mana yang sesuai dengan karyawannya. Selain itu, perilaku dan sifat karyawan juga berpengaruh terhadap pemilihan jenis pendisiplinan mana yang dapat diterapkan kepada karyawan. Terdapat beberapa tipe kegiatan pendisiplinan menurut Handoko (2008), antara lain adalah :

1. Disiplin Preventif adalah kegiatan yang dilaksanakan untuk mendorong para karyawan agar mengikuti berbagai standar dan aturan, sehingga penyelewengan dapat dicegah.

2. Disiplin Korektif adalah kegiatan yang diambil untuk menangani pelanggaran terhadap aturan dan mencoba untuk menghindari pelanggaran lebih lanjut.

3. Disiplin Progresif adalah memberikan hukuman yang lebih berat terhadap pelanggaran yang berulang.

Sasaran pokok dari disiplin preventif adalah untuk mendorong disiplin diri di antara para karyawan, dengan cara ini para karyawan dapat menjaga disiplin diri mereka bukan semata-mata karena dipaksa manajemen. Manajemen harus mempunyai tanggung jawab untuk menciptakan suatu iklim disiplin preventif di mana berbagai standar diketahui dan dipahami. Bila para karyawan tidak mengetahui standar-standar apa yang harus dicapai, mereka cenderung menjadi salah arah. Di samping itu, manajemen hendaknya menetapkan standar-standar secara positif dan bukan secara negatif. Para karyawan biasanya perlu mengetahui alasan-alasan yang melatar belakangi suatu standar agar mereka dapat memahami dan menjalankannya, sedangkan 
pada disiplin korektif kegiatannya biasanya dapat diaplikasikan dalam suatu bentuk hukuman atau disebut juga sebagai tindakan pendisiplinan. Tindakan pendisiplinan ini dapat berupa peringatan maupun skorsing. Adapun sasaran tindakan pendisiplinan dapat dibagi menjadi tiga menurut Handoko (2008), antara lain untuk memperbaiki pelanggar, untuk menghalangi para karyawan yang lain melakukan kegiatan-kegiatan yang serupa, dan untuk menjaga berbagai standar kelompok tetap konsisten dan efektif.

Disiplin progresif dijalankan dengan tujuan untuk memberikan kesempatan kepada karyawan untuk mengambil tindakan korektif sebelum hukuman yang lebih serius diberikan. Disiplin progresif memungkinkan manajemen untuk membantu karyawan memperbaiki kesalahannya. Tindakan pendisiplinan dapat diberikan berurut, misalnya : teguran secara lisan oleh pimpinan, setelah itu teguran tertulis, dengan catatan dalam file personalia, skorsing dari pekerjaan dalam jangka waktu tertentu, penurunan jabatan (demosi), dan yang terakhir pemecatan. Bentuk tindakan pendisiplinan terakhir yang dapat diambil oleh manajemen perusahaan adalah pemecatan. Tindakan ini sering dikatakan sebagai kegagalan manajemen sumber daya manusia, tetapi pandangan tersebut tidaklah realistik. Tidak ada manajer maupun karyawan yang sempurna, sehingga hampir pasti ada saja berbagai masalah yang tidak dapat dipecahkan.

Menurut Simanora (2006) menyatakan bahwa tujuan tindakan disipliner yaitu :

1. Menanamkan sifat konsisten. Tujuan utama tindakan disipliner adalah memastikan bahwa perilaku karyawan konsisten dengan aturan perusahaan.

2. Menciptakan hubungan yang sinergis antara atasan dengan bawahan, tujuan disipliner yang kedua adalah menciptakan atau mempertahankan rasa hormat dan saling percaya diantaranya penyelia dan bawahannya. Disiplin yang diberlakukan secara tepat dapat menciptakan masalah-masalah seperti modal kerja yang rendah, kemarahan dan kemauan buruk diantara penyelia dan bawahan-bawahannya. Kondisi yang seperti itu, setiap perbaikan dalam perilaku karyawan hanya aka berlangsung singkat dan penyelia harus mendisiplinkan kembali karyawan dalam jangka waktu yang tidak terlalu lama. Pelaksanaan tindakan pendisiplinan yang benar tidak hanya memperbaiki perilaku karyawan, tetapi juga akan meminimalkan masalah-masalah disipliner di masa yang akan datang melalui hubungan yang positif diantara penyelia bawahan.

3. Meningkatkan produktifitas karyawan. Tindakan disipliner dapat pula membantu karyawan supaya menjadi kineja yang pada akhirnya menghasilkan pencapaian pada individu tersebut lebih produktif, dengan demikian menguntungkannya dalam jangka panjang. Misalnya, jika seorang karyawan didisiplinkan karena kegagalan memantau kualitas keluarganya dan kualitas di tingkat setelah tindakan disiplin hal ini akan berfaedah dalam mengembangkan karyawan yang bersangkutan. Karyawan diingatkan mengenai apa yang diharapkan dan memenuhi persyaratan-persyaratan tersebut dengan lebih baik. Tindakan disiliner yang efektif dapat mendorong individu untuk meningkatkan kinerja dan hasil produktivitas.

Menurut Handoko (2008), suatu organisasi dapat mengambil beberapa pendekatan terhadap disiplin, terdapat empat perspektif daftar yang menyangkut disiplin kerja yaitu :

1. Disiplin retributif yaitu berusaha menghukum orang yang berbuat salah.

2. Disiplin korektif yaitu berusaha membantu karyawan mengoreksi perilakunya yang tidak tepat.

3. Perspektif hak-hak individu yaitu berusaha melindungi hak-hak dasar individu selama tindakan-tindakan disipliner.

4. Perspektif utilitarian yaitu berfokus kepada penggunaan disiplin hanya pada saat konsekuensi-konsekuensi tindakan disiplin melebihi dampak-dampak negatifnya.

Indikator disiplin kerja menurut Soejono (2000) ada beberapa indikator disiplin kerja karyawan yaitu sebagai berikut: 
1. Ketepatan waktu. Para karyawan datang ke kantor tepat waktu, tertib dan teratur, dengan begitu dapat dikatakan disiplin kerja yang baik.

2. Menggunakan peralatan kantor dengan baik. Sikap hati-hati dalam menggunakan peralatan kantor dapat mewujudkan bahwa seseorang memiliki disiplin kerja yang baik, sehingga peralatan kantor dapat terhindar dari kerusakan.

3. Tanggung jawab yang tinggi. karyawan yang senantiasa menyelesaikan tugas yang dibebankan kepadanya sesuai dengan prosedur dan bertanggung jawab atas hasil kerja, dapat pula dikatakan memiliki disiplin kerja yang baik.

4. Ketaatan terhadap aturan kantor. karyawan memakai seragam kantor, menggunakan kartu tanda pengenal/identitas, membuat ijin bila tidak masuk kantor, juga merupakan cerminan dari disiplin yang tinggi.

Mangkunegara (2002) menyatakan kinerja adalah hasil kerja baik secara kualitas maupun kuantitas yang dicapai oleh seseorang dalam melaksanakan tugas sesuai tanggung jawab yang diberikan. Sedangkan Juliansyah (2013) menyebutkan kinerja adalah hasil yang dicapai karyawan atau karyawan menurut ukuran yang berlaku untuk pekerjaan yang bersangkutan.

Kinerja adalah kuantitas atau kualitas sesuatu yang dihasilkan atau jasa yang diberikan oleh seseorang yang melakukan pekerjaan (Luthans, 2005). Payaman (2005) menyatakan bahwa kinerja pada dasarnya adalah apa yang dilakukan atau tidak dilakukan karyawan. Kinerja adalah tingkat pencapaian hasil atas pelaksanaan tugas tertentu.

Kesimpulan dari pengertian kinerja ini adalah hasil kerja seorang pekerja, sebuah proses manajemen atau suatu organisasi secara keseluruhan, dimana hasil kerja tersebut harus dapat ditunjukkan buktinya secara konkrit dan dapat diukur.

Tujuan melakukan penilaian kinerja karyawan oleh suatu perusahaan melakukan penilaian kinerja didasarkan pada dua alasan pokok, yaitu :
1. Manajer melakukan evaluasi yang objektif terhadap kinerja karyawan pada masa lalu yang digunakan untuk membuat keputusan di bidang SDM di masa yang akan datang.

2. Manajer memerlukan alat yang memungkinkan untuk membantu karyawannya memperbaiki kinerja, merencanakan pekerjaan, mengembangkan kemampuan dan keterampilan untuk perkembangan karier dan memperkuat kualitas hubungan antar manajer yang bersangkutan dengan karyawannya.

Menurut Rivai dan Sagala (2013), selain itu penilaian kinerja dapat digunakan untuk mengetahui perkembangan, pengambilan keputusan administratif, keperluan perusahaan dan dokumentasi.

Kegunaan penilaian kinerja ditinjau dari berbagai perspektif pengembangan perusahaan, khususnya manajemen SDM. Dokumentasi digunakan untuk memperoleh data yang pasti, sistematik, dan faktual dalam penentuan nilai suatu pekerjaan. Menurut Rivai dan Sagala (2013), kegunaan penilaian kinerja ada banyak, diantaranya sebagai upaya perbaikan kinerja, penyesuaian kompensasi, dan perencanaan karier.

Penyelia sering tidak berhasil untuk meredam emosi dalam menilai prestasi kinerja karyawan, hal ini menyebabkan penilaian menjadi bias. Bias adalah distorsi pengukuran yang tidak akurat. Menurut Rivai dan Sagala (2013) Bias ini mungkin terjadi sebagai akibat ukuran yang digunakan bersifat subjektif. Berbagai bentuk bias yang umum terjadi adalah:

1. Kendala hukum atau legal, penilaian kinerja harus bebas dari diskriminasi tidak sah atau tidak legal. Apapun format penilaian kinerja yangdigunakan oleh departemen SDM harus sah dan dapat dipercaya. Jika hal tersebut tidak dipenuhi, keputusan penempatan mungkin ditentang sebab melanggar hukum ketenagakerjaan atau hukum lainnya. Oleh karena itu, setiap keputusan hendaknya objektif dan sesuai dengan hukum.

2. Bias oleh penilai, setiap masalah yang didasarkan pada ukuran subjektif adalah 
peluang terjadinya bias. Bentuk-bentuk bias yang umumnya terjadi adalah :

a. Hallo Effect. hallo effect terjadi ketika pendapat pribadi penilai mempengaruhi pengukuran kinerja baik dalam arti positif maupun negatif.

b. Kesalahan kecenderungan terpusat. Beberapa karyawan tidak suka menempatkan karyawan ke posisi ekstrim dalam arti ada karyawan yang dinilai sangat positif atau sangat negatif. Penilaian demikian sering di hindari karena penilai harus menjelaskan kepada departemen SDM mengenai alasan dari penilaian seperti itu.

c. Bias karena terlalu lunak dan terlalu keras. Bias terlalau lunak terjadi ketika penilai cenderung begitu mudah dalam mengevaluasi kinerja karyawan. Bias terlalu keras adalah kebalikannya, diakibatkan oleh penilai yang terlalu ketat dalam mengevaluasi mereka.

d. Bias karena penyimpang lintas budaya. Setiap penilai mempunyai harapan tentang tingkah laku manusia yang didasarkan pada kulturnya. Ketika seorang penilai diharuskan untuk menilai dari karyawan yang berbeda kulturnya, mereka mungkin menerapkan budayanya terhadap karyawan tersebut.

e. Prasangka pribadi. Sikap tidak suka seorang penilai terhadap sekelompok orang tertentu dapat mengaburkan hasil penilaian seorang karyawan.

f. Pengaruh kesan terakhir. Ketika penilai diharuskan menilai kinerja karyawan pada masa lampau, kadang-kadang penilai mempersepsikan dengan tindakan karyawan pada saat ini yang sebetulnya tidak berhubungan dengan kinerja masa lampau.

3. Mengurangi bias penilaian, Bias ini dapat dikurangi melalui standar penilaian dinyatakan secara jelas, pelatihan, umpan balik, dan pemilihan teknik penilaian kinerja yang sesuai.

Metode atau teknik penilaian kinerja karyawan dapat digunakan dengan pendekatan yang berorientasi masa lalu dan masa depan. Dalam praktiknya tidak ada satupun teknik yang sempurna, pasti ada saja keunggulan dan kelemahannya. Hal penting adalah bagaimana cara meminimalkan masalah yang mungkin terdapat pada setiap teknik yang digunakan. Metode penilaian kinerja menurut Rivai dan Sagala (2013), yaitu metode penilaian berorientasi masa lalu dan metode penilaian berorientasi masa depan.

Menurut Simamora (2006), indikator-indikator yang digunakan dalam pengukuran kinerja meliputi kuantitas kerja, kualitas kerja, dan ketepatan waktu. Kuantitas kerja merupakan suatu hasil yang dicapai oleh karyawan/pekerja dalam jumlah tertentu dengan perbandingan standar yang ada atau telah ditetapkan oleh lembaga/perusahaan. Kualitas kerja merupakan suatu standar hasil yang berkaitan dengan mutu dari suatu produk yang dihasilkan oleh pekerja, dalam hal ini merupakan suatu kemampuan pekerja dalam menyelesaikan pekerjaan secara teknis dengan perbandingan standar yang telah ditetapkan oleh lembaga/perusahaan. Ketepatan waktu merupakan tingkat suatu aktivitas yang diselesaikan pada awal waktu yang telah ditentukan, dilihat dari sudut koordinasi dengan hasil output, serta mampu memaksimalkan waktu yang tersedia untuk aktivitas lain. Ketepatan waktu diukur dari persepsi pekerja terhadap suatu aktivitas yang disediakan di awal waktu sampai menjadi output.

Kedisiplinan yang baik dapat terwujud, misalnya bila para karyawan tersebut datang ke tempat kerja dengan teratur dan tepat pada waktunya, apabila mereka berpakaian baik pada tempat pekerjaannya, mereka menggunakan bahan-bahan dan perlengkapan dengan hati-hati, apabila mereka menghasilkan produktivitas yang maksimal sesuai jam yang telah ditentukan perusahaan dan kualitas pekerjaan yang memuaskan dan mengikuti cara bekerja yang ditentukan oleh perusahaan dengan semangat yang baik. Contohnya yang dihasilkan, apabila karyawan yang datang ke pabrik tepat pada waktunya, maka dapat dipastikan kuantitas yang dihasilkan lebih banyak ketimbang karyawan yang datang ke pabrik terlambat. Kedisiplinan 
sangat penting, karena tanpa ada kedisiplinan yang timbul dari dalam diri karyawan sendiri biasanya mempengaruhi tingkat kinerja karyawan dan produktivitas kerja. Adanya peraturan kedisiplinan maka akan mempengaruhi karyawan untuk bekerja dengan baik, sehingga akan mendapatkan hasil yang lebih optimal. Kedisiplinan yang baik akan dapat meningkatkan kinerja karyawan dan produktivitas kerja yang bertambah baik dengan hasil yang baik.

\section{Metode Penelitian}

Populasi dalam penelitian ini adalah seluruh karyawan PT. Panca Konstruksi berjumlah 98 orang yang bekerja dikantor. Pemilihan sampel untuk penelitian ini dilakukan secara Purposive Sampling yaitu populasi yang dijadikan sampel adalah populasi yang memenuhi kriteria tertentu dengan tujuan agar sampel yang diambil bisa lebih representatif dengan kriteria yang telah ditentukan. Untuk mendapatkan sampel yang dapat menggambarkan populasi, digunakan rumus Slovin dengan tingkat kesaalahan $10 \%$, sehingga diperoleh sampel sebanyak 57 orang.

Pengukuran yang digunakan untuk mengukur instrumen variabel penelitian diperoleh melalui jawaban responden dengan memberikan tanda pada setiap kategori pernyataan yang disusun berdasarkan skala Likert dengan rentang 5 level. Setiap jawaban responden akan diberi skor dan jumlah skor menunjukkan tinggi rendahnya masing-masing variabel yang diukur. Skor yang diberikan pada setiap jawaban responden adalah sangat setuju (SS), setuju (S), kurang setuju (KS), tidak setuju (TS), serta sangat tidak setuju (STS).

Teknik

pengumpulan

data

menggunakan daftar pertanyaan (angket) yang telah disiapkan untuk seluruh responden.

Kemudian didukung dengan adanya wawancara langsung dengan responden serta penggunaan dokumen untuk melengkapi data yang belum lengkap pada data primer. Angket sifatnya tertutup, artinya responden dapat memilih salah satu dari beberapa alternatif jawaban yang telah disediakan atas suatu pertanyaan atau pernyataan dengan menggunakan Skala Model Likert, dimana masing-masing pertanyaan diberi skor dari yang nilainya sangat positif sampai menjadi negatif.

Variabel bebas yang digunakan adalah disiplin kerja $(X)$ yaitu sebagai suatu sikap, tingkah laku dan perbuatan yang sesuai dengan peraturan perusahaan baik yang tertulis maupun tidak, yang dilihat dari ketepatan waktu $\left(\mathrm{X}_{1.1}\right)$, menggunakan peralatan kantor dengan baik $\left(\mathrm{X}_{1.2}\right)$, tanggung jawab yang tinggi $\left(\mathrm{X}_{1.3}\right)$, dan ketaatan terhadap aturan kantor $\left(\mathrm{X}_{1.4}\right)$. Sedangkan variabel terikat yang digunakan adalah kinerja karyawan (Y) yaitu kuantitas dan kualitas sesuatu yang dihasilkan atau jasa yang diberikan oleh seseorang yang melakukan pekerjaan. Indikator kinerja terdiri dari kuantitas kerja $\left(\mathrm{Y}_{1.1}\right)$, kualitas kerja $\left(\mathrm{Y}_{1.2}\right)$, dan ketepatan waktu $\left(\mathrm{Y}_{1.3}\right)$.

Metode analisis yang digunakan untuk penelitian ini adalah metode analisis regresi linier sederhana. Analisis data dilakukan melalui beberapa tahapan seperti uji validitas, uji reliabilitas, analisis regresi sederhana dan uji t maupun uji F. Untuk analisis data ini menggunakan program pengolahan data yaitu program SPSS 18.

\section{Hasil Penelitian Dan Pembahasan}

Data variabel penelitian yang telah di uji validitas dan reliabilitasnya serta dinyatakan valid dan reliabel kemudian dimasukkan pada estimasi regresi sehingga hasilnya dapat disusun persamaan regresi sederhana sebagai berikut:

$Y=20.425+0,681 X$

Persamaan regresi sederhana ini dapat diuraikan bahwa nilai konstanta koefisien regresi sebesar 20.425 menunjukkan pentingnya disiplin kerja bagi karyawan PT. Panca Konstruksi. Jika disiplin kerja ditingkatkan satu kali maka kinerja karyawan akan meningkat sebesar 0,681. Dengan kata lain bahwa konstanta sebesar 20.425 menunjukkan arti bahwa jika disiplin kerja (X) nilainya sama dengan 0, maka Kinerja karyawan (Y) nilainya sebesar 20.425. kemudian koefisien regresi variable disiplin kerja (X) sebesar 0.681 menunjukkan arti bahwa apabila disiplin kerja $(\mathrm{X})$ mengalami 
kenaikan 1 kali maka kinerja (Y) juga akan mengalami peningkatan sebesar 0.681 .

Nilai koefisien regresi untuk indikator disiplin kerja (X) terhadap Kinerja (Y) sebesar 0,681 memiliki arti bahwa terdapat pengaruh yang positif antara disiplin kerja dengan kinerja karyawan, sehingga jika terjadi peningkatan pada disiplin kerja ini maka Kinerja (Y) karyawan akan naik sebesar 0,681 kali dengan menganggap indikator yang lain tetap. Berdasarkan hasil analisis data dapat diketahui bahwa $\mathrm{t}$ hitung untuk variabel disiplin kerja ditemukan hasil sebesar 8.448 lebih besar dari $t$ tabel 1.676, artinya hipotesa (Ho) secara keseluruhan ditolak dan sebaliknya hipotesis alternatif (Ha) secara keseluruhan diterima, dimana variabel disiplin kerja berpengaruh signifikan secara statistik terhadap kinerja karyawan.

Secara simultan indikator disiplin kerja (X) berpengaruh signifikan terhadap kinerja (Y) karyawan PT. Panca Konstruksi karena pada taraf signifikansi 5\% nilai F-hitung $71.368>$ nilai F-tabel 2,199. Dengan demikian variabel disiplin kerja $(\mathrm{X})$ memiliki kontribusi sebesar 71.368 terhadap variabel kinerja (Y) secara signifikan.

Nilai koefisien determinan sebesar 0,565 untuk dependent Kinerja (Y) mempunyai makna bahwa semua indikator disiplin kerja (X) yang diajukan dalam penelitian ini serta telah bebas dari masalah multikolinieritas, heteroskedastisitas dan autokolerasi mempunyai kontribusi sebesar $56,5 \%$ terhadap variansi Kinerja (Y) karyawan PT. Panca Konstruksi. Sedangkan sisanya sebesar $43,5 \%$ ditentukan oleh variabel lain yang tidak termasuk dalam penelitian ini.

Dengan demikian, peningkatan disiplin kerja karyawan dapat dilakukan dengan berbagai cara sesuai dengan situasi dan kondisi dari perusahaan tersebut. Dalam hal ini tentu saja memerlukan peran pimpinan, baik pimpinan unit kerja maupun pimpinan secara keseluruhan. Karena pencapaian laba perusahaan dalam hal ini sangat ditentukan oleh keberhasilan dari kinerja seluruh karyawan dalam melaksanakan semua tugas-tugasnya sesuai dengan fungsinya dalam perusahaan tersebut.
Dari analisis data tersebut menunjukkan bahwa faktor disiplin kerja sangat penting untuk diterapkan secara baik pada semua karyawan PT. Panca Konstruksi. Disiplin yang baik mencerminkan besarnya tanggung jawab karyawan terhadap tugas-tugas yang diberikan. Disiplin lebih banyak bersumber dari dalam diri karyawan itu sendiri yang diperlihatkan dalam bentuk mematuhi peraturan yang ada pada karyawan PT. Panca Konstruksi, menyelesaikan tugas tepat waktu, Untuk memelihara dan menegakkan disiplin yang baik ada banyak yang mempengaruhinya diantaranya adalah kesejahteraan, pendidikan dan pelatihan, motivasi, kepemimpinan, budaya organisasi dan lingkungan kerja.

Dengan adanya hubungan yang signifikan antara disiplin kerja dengan kinerja karyawan PT. Panca Konstruksi, maka tindakan disiplin hendaknya bersikap positif, bukan tindakan negatif yang menjatuhkan karyawan yang berbuat salah karena disiplin bertujuan untuk memperbaiki kegiatan dimasa yang akan datang bukan menghukum kegiatan dimasa lalu.

Kedisiplinan merupakan suatu hal yang menjadi tolak ukur bagi karyawan PT. Panca Konstruksi untuk mengetahui apakah peran karyawan secara keseluruhan dapat dilaksanakan dengan baik atau tidak. Disiplin juga merupakan bentuk pengendalian diri karyawan dan pelaksanaan yang teratur menunjukkan tingkat kesungguhan tim kerja dalam perusahaan, tindakan disiplin menuntut adanya hukuman terhadap karyawan yang gagal memenuhi standar yang ditentukan. Oleh karena itu tindakan disiplin tidak diterapkan secara sembarangan dan asal asalan, melainkanmemerlukan sebuah pertimbangan yang bijak.

Oleh sebab itu pada PT. Panca Konstruksi, disiplin kerja adalah suatu sikap dan perilaku yang dilakukan secara sukarela dan penuh kesadaran serta keadaan untuk mengikuti peraturan yang telah ditetapkan perusahaan baik tertulis maupun tidak tertulis. Perilaku tidak disiplin yang timbul merupakan cerminan dari persepsi negatif karyawan terhadap kontrol yang dilakukan oleh perilaku pimpinan. Sebaliknya perilaku disiplin seorang karyawan yang timbul 
merupakan cerminan dari persepsi positif terhadap kontrol atasan atau pimpinan.

Kepemimpinan secara parsial memiliki pengaruh yang signifikan terhadap kedisiplinan kerja karyawan pada PT. Panca Konstruksi. Hal ini menunjukkan bahwa pemimpin yang tegas dalam melaksanakan aturan yang berlaku, pemimpin adil dalam pemberian sanksi kepada semua karyawan yang melanggar, dengan adanya hal ini akan dapat mendorong rasa kedisiplinan kerja karyawan untuk mencapai kinerja yang diinginkan oleh perusahaan.

Mengingat manusia merupakan unsur terpenting dalam suatu organisasi, bahkan faktor manusia dapat merupakan faktor perangsang ke arah tercapainya tujuan perusahaan secara efektif dan efisien. Dalam hal yang demikian, maka manusia merupakan modal terpenting bagi perusahaan, sebaiknya dapat terjadi bahwa manusia juga menjadi faktor utama ke arah tercapainya tujuan yang telah ditentukan. Untuk itu pimpinan perusahaan dituntut untuk memenuhi keberadaan karyawannya. Karena perilaku yang akan diwujudkan cenderung diwarnai hakekat tujuan yang dicapai. Meskipun pada dasarnya yang bersangkutan tidak selalu menyadari adanya ikatan tujuan perusahaan yang dituntut kepadanya.

Masalah kedisiplinan kerja merupakan masalah yang perlu diperhatikan. Sebab dengan adanya kedisiplinan maka akan dapat mempengaruhi efektifitas dan efisiensi pencapaian tujuan perusahaan. Disiplin yang baik mencerminkan besarnya rasa tanggung jawab seseorang terhadap tugas-tugas yang diberikan kepadanya. Hal ini mendorong gairah kerja, semangat kerja dan terwujudnya tujuan perusahaan melalui peningkatan kinerja yang diberikan oleh karyawan.

Dalam hal ini, faktor disiplin dipandang sebagai suatu aspek yang sangat penting. Karena melalui disiplin kerja ini dapat diciptakan kesadaran dari setiap pribadi karyawan PT. Panca Konstruksi dan terhadap eksistensinya serta kontribusi yang dituntut kepadanya dalam rangka mencapai tujuan PT. Panca Konstruksi dan pribadinya. Yang dimaksud dengan disiplin dalam tulisan ini adalah usaha yang dilakukan untuk menciptakan keadaan disuatu lingkungan kerja yang tertib, beradaya guna berhasil guna melalui suatu sistem pengaturan yang tepat atau dengan kata lain disiplin adalah ketaatan terhadap peraturan yang berlaku sehingga akan menghasilkan kondisi kinerja karyawan yang prima.

Disiplin yang baik tercermin dari besarnya rasa tanggung jawab seseorang terhadap tugas yang diberikan kepadanya. Maka peraturan sangat diperlukan untuk memberikan bimbingan dan penyuluhan bagi karyawan dalam menciptakan tata tertib yang baik di dalam organisasi, sebab kedisiplinan suatu organisasi dikatakan baik jika sebagian karyawan mentaati peraturan-peraturan yang ada.

Dalam kaitan ini, faktor disiplin dipandang sebagai suatu aspek yang penting karena melalui disiplin ini dapat diciptakan kesadaran dari setiap anggota organisasi terhadap eksistensi serta konstribusi yang dituntut dari padanya dalam rangka mencapai tujuan organisasi.

Seseorang akan bersedia disiplin dan mematuhi semua peraturan serta melaksanakan tugas-tugasnya, baik secara sukarela maupun karena terpaksa. Oleh karena itu kedisiplinan diartikan jika karyawan selalu datang dan pulang tepat pada waktunya, mengerjakan semua pekerjaan dengan baik, mematuhi semua peraturan perusahaan, organisasi dan norma-norma sosial yang berlaku.

Salah satu bentuk dari kewajiban manusia sebagai anggota organisasi adalah ketaatan terhadap aturan-aturan serta prosedur yang berlaku di dalam organisasi secara umum ketaatan inilah yang disebut disiplin. Apakah tata aturan itu hasil perdebatan secara be bas ataukah diperlukan tanpa didiskusikan terlebih dahulu, apakah hasil perjanjian antara pihak-pihak yan bersangkutan atau dari undang-undang dan atau dari kebiasaan-kebiasaan pokok tata aturan itulah yang memberikan corak kepada disiplin itu.

Sedangkan kinerja merupakan hasil kerja yang dapat dicapai oleh karyawan atau sekelompok karyawan dalam suatu organisasi yang sesuai wewenang dan tanggung jawab masing-masing dalam upaya mencapai suatu tujuan organisasi yang bersangkutan. Dan juga sesuai dengan hukum, moral dan etika 
serta standar kerja telah ditetapkan berdasarkan kriteria pekerjaan. Kinerja merupakan hasil kerja yang dapat di capai oleh karyawan atau sekelompok karyawan dalam suatu organisasi, sesuai dengan wewenang dan tanggung jawab masing-masing dalam rangka upaya mencapai tujuan organisasi bersangkutan secara legal, tidak melanggar hukum dan sesuai dengan moral maupun etika.

Setiap karyawan dalam melaksanakan tugas dan kewajiban merasa bahwa hasil kerja mereka tidak terlepas dari penilaian alasan yang baik, baik itu secara langsung maupun tidak langsung. Penilaian kinerja mempunyai kegunaan yaitu untuk mengukur kinerja untuk tujuan memberikan penghargaan, dan untuk pengembangan potensi individu dalam melaksanakan tugas dan fungsi yang merupakan tanggung jawabnya.

Dampak dari sikap disiplin kerja terhadap kinerja karyawan PT. Panca Konstruksi di Kabupaten Banjar yang memuaskan menurut penelitian ini mempercepat tercapainya tujuan, visi dan misi, tercapainya standar kerja yang diharapkan mendorong perilaku-perilaku yang diinginkan, menumbuhkan rasa tanggung jawab, sedangkan dampak dari disiplin kerja yang tidak memuaskan, karyawan mengalami kesulitan dalam menyelesaikan tugasnya serta akan muncul berbagai masalah yang menyangkut pencapaian kinerja selama ini.

\section{Kesimpulan}

Hasil uji yang dilakukan secara simultan diketahui bahwa variabel disiplin kerja berpengaruh signifikan terhadap kinerja karyawan pada PT. Panca Konstruksi di Kabupaten Banjar, Dar nilai koefisien determinasi sebesar dapat disimpulkan bahwa tingkat kedisiplinan memang memiliki andil yang cukup besar dalam menentukan tingkat kinerja karyawan di PT. Panca Konstruksi di Kabupaten Banjar. Berdasarkan hasil penelitian ini maka disarankan agar PT. Panca Konstruksi di Kabupaten Banjar lebih memperhatikan masalah disiplin kerja karena terbukti berpengaruh terhadap kinerja karyawan.

\section{DAFTAR PUSTAKA}

Alex, S. Nitisemitro. 2006. Manajemen Personalia, Ghalia Indonesia, Jakarta

Handoko, T. Hani. 2008. Manajemen Personalia dan Sumberdaya Manusia, BPFE, Yogyakarta

Juliansyah. 2013. Penelitian Ilmu Manajemen Tinjauan Filosofis Dan

Praktis, Kencana Prenada Media Group, Jakarta

Luthans, F. 2005. Organizational Behavior, McGraw-Hill, New York

Mangkunegara, Anwar Prabu. 2002. Manajemen Sumber Daya Manusia. Remaja Rosdakarya, Bandung

Melayu, S.P. Hasibuan. 2007. Manajemen Sumber Daya Manusia, Bumi Aksara, Jakarta

Rivai, Veithzal dan Jauvani Sagala, Ella. 2013. Manajemen Sumber Daya Manusia Untuk Perusahaan. PT. RajaGrafindo Persada, Jakarta

Simamora, Henry. 2006. Manajemen Sumber Daya Manusia, YKPN, Yogyakarta

Sondang, Siagian P. 2008. Manajemen

Sumber Daya Manusia, Bumi Aksara, Jakarta

Soejono. 2000. Sistem Dan Prosedur Kerja, Bumi Aksara, Jakarta 